\title{
Developing a Model for Sustainable Conversion of Blockhouse Bunkers in Serbia
}

\author{
Branko Anton-Jožef TURNŠEK, Ana STANOJEVIĆ, Ljiljana JEVREMOVIĆ
}

\begin{abstract}
Blockhouses represent a type of small-span aboveground bunkers, originally built in England but later also in other parts of the world. These specific forms of military heritage, which were largely built during the WWII in Balkan, are forgotten witnesses of the past. As the old military concepts and doctrines have been abandoned, the strategic interest for the blockhouses has been lost, while the questions about their future arose. While the developed countries are actively engaged in the search for sustainable solutions that consider finding the non-military uses for these military structures, it is still quite a rarity in Serbia. Many blockhouses are located in the areas of outstanding natural values or within the urban zones; so consequently, they do have a potential to be integrated into contemporary urban dynamics. The paper examines reasons and possibilities for the reuse of blockhouse bunkers, taking into account the principles of sustainability and the indicators for adaptability, analysing their spatial, functional transformation through the development of a model for sustainable conversion. In order to check the debated postulates, a design proposal of a blockhouse converted into a single-family house is presented and discussed from the aspect of layout flexibility and development of a modular extension, as a plausible and sustainable scenario.
\end{abstract}

Keywords: blockhouse; bunker; conversion; Serbia; sustainable model

\section{INTRODUCTION}

"Tradition and innovation do not have to represent two conflicting sides. Common thinking about values, ideas and dreams are important cultural resources" [1].

The contemporary strategies for sustainable urban and rural development are highly focused on the management of abandoned buildings and their recycling due to the intensive urban, socio-political, cultural and economic transformations. The space in urban areas is a limited resource and therefore the vacant and underused facilities and their renewal and reuse have become a more apparent problem [2]. Revitalization and conversion of old built structures are recognized as sustainable methods that can provide adequate protection and preservation of history and architectural integrity of the buildings [3, 4]. Preservation of the historical built structures contributes to sustain and nurture the identity of a place; the retained buildings are given a new dimension, while their significance has been revalorized within the changed environment. Also, the reuse of old buildings contributes to reduction of negative impact on the environment by material recycling and energy conservation [5].

Both, geopolitical changes and the reassessment of military doctrines have led to the abandonment of military facilities, including some types of bunkers. The paper is focused on blockhouses, as a specific type of aboveground bunkers, which represent small fortifications and watchtowers, built from XVI to mid-XX century on almost all continents [6,7]. The territory of the Balkans is characterized by a large number of blockhouses, built during the Second World War (WWII), which are, nowadays, mostly abandoned and/or partially devastated. These facilities have not been placed under the protection regime. As such, there is a need to re-examine their future and possibilities in the context of sustainability. A high degree of preservation makes a demolition economically unprofitable, while the authenticity, construction and site benefits make them suitable for conversion.

Starting from the analysis of the factors that influence conversion capability and the principles of sustainable development, the paper deals with the specifics of the blockhouses built in Serbia. Focusing on their morphological characteristics, this research aims to identify the principles of the sustainable transformation and reuse of the blockhouses and finally to develop a sustainable model of such conversion.

As the intermediaries to the realization of the primary goal, the other aims of the research are:

- to identify the spatial and physical attributes of blockhouses that affect their adaptability;

- to recognize other important factors that affect conversion: urban context, social importance and preservation degree;

- $\quad$-to examine historical narrative and characteristics of blockhouses: their specificities, current state, treatments and interventions seen in the past practice;

- to evaluate parameters identified in the theory by testing a reuse capability of blockhouses;

- to identify plausible interventions on blockhouse structure (in terms of spatial, functional and aesthetic transformations) in order to form a model for sustainable conversion;

- to confirm the model of sustainable conversion by analysis of a concrete design proposal of a reuse.

\section{PRINCIPLES OF SUSTAINABILITY AND INFLUENCING FACTORS ON CONVERSION}

According to the generally accepted definition, "sustainable development represents an integral economic, technological, social and cultural development, compliant with the needs for protection and improvement of the environment, which allows current and future generations to satisfy their needs and improve the quality of life" [1]. Sustainable development is a complex matrix of economic, environmental and social sustainability. There are two additional pillars of sustainability: cultural and institutional, which at certain moments can be of the primary importance. The cultural dimension refers to all types of tangible and intangible cultural assets and built heritage that should be preserved and incorporated in a contemporary urban matrix, interacting with immediate physical surroundings (as the spatial environment) and 
local communities (as the social environment) in which the process takes place [8]. The sustainable development concerns and tasks at the local institutional level means [1]: creation of the partnership, analysis of problems based on community needs [9], action planning, implementation and monitoring. Institutional dimension has been defined as a set of measures that allow the application of the named tasks in practice [10].

Sustainable development usually means acting with a complex matrix of interactive influences, which ultimately shape the conversion of existing structures and space. Physical space must be in the context of an environment and in accordance with its developmental needs, taking into account the interests of the social community and preserving cultural, historical and ambient values. The environmental responsibility is developed by promoting ecological awareness, protection of historical heritage, buildings restoration and recycling, improvement of energy efficiency, considering possible ways of implementation and by realization of plans and economic sustainability [4]. Based on several authors and documents (Bentley, Barton, Commission of the European Community, URBED and etc. [11]), Carmona (2009) systematizes the matrix of the principles of the sustainable design by spatial scale, emphasizing, inter alia, diversity\&choice, distinctiveness, human needs, concentration, resilience and resource efficiency, as important elements of the sustainability of physical space, at four levels, with the buildings on the lowest level [12].

In the process of reuse of the buildings, physical parameters strongly determine the possibility of conversion. Namely, the transformation into new purposes is plausible only if there are certain spatial capacities and the qualities of the existing structure. The studies of Duffy (1990), Moudon (1987), Brand (1994), and LlewelynDavies (2000) identified the key spatial factors affecting the adaptability of buildings: size (depth) of the building, form of interior space volume and access to the building. The depth of a building and its interior volume influence the possibility of natural lighting and ventilation of the interior space [13], as well as on the layout flexibility, capacity for division into smaller spatial units and consequently optimal new purpose $[14,15]$. The height of the building, the number and the position of the access points determine the connection with the surrounding and the ambient value in the context of the new purpose [16]. If spatial capacity of existing structure is limited, a conversion and reuse options are reduced or even not plausible [11].

So, in order to examine the reuse possibilities of the abandoned buildings and to find a model for sustainable solution, it is necessary to analyse and valorise the corresponding urban and architectural parameters defined as follows [17]:

dimensional parameters (height/number of floors /depth of the building)-affect the real physical and spatial capacities of existing structures;

site parameters (the position of the building within the urban area, the character of surrounding urban uses, the environmental quality and the access to the building)-new use should be in accordance with building's immediate environment, in terms of physical and social context; parameters regarding degree of structure preservation and authenticity-affect the degree and method of constructive-architectural interventions in the conversion process.

\section{BLOCKHOUSE BUNKERS}

Narrowly speaking, military fortifications, partially or completely underground, are defined as bunkers while aboveground fortifications and shelters for people and war equipment are designated as blockhouses. In Germany, any aboveground bunker, regardless of its purpose and size, is defined as a blockhouse. English blockhouses are facilities whose purpose is limited to the watchtowers but also with the defence assignments. Nowadays, the generally accepted definition is that blockhouses are smaller military fortifications in the form of individual structure with one or more rooms with loopholes, which allow firing in different directions [6].

\subsection{Historical Development and Main Features}

The first blockhouses were built in England during the reign of Henry VIII, in the XVI century, as part of the coastal fortification [18], as a stone tower of circular, square or irregular shape of the basis (Fig. 1 left). Blockhouses were mass-built in the XVIII and XIX centuries in Europe (England, Austro-Hungarian and Prussian) [7], and during the Boer War in South Africa [19]. In the mid-XVIII century, the British transferred them to the American continent. The blockhouses from this period were characterized by a square plan, a wooden log construction, with an upper floor console, about $60 \mathrm{~cm}$ over the lower floors, in order to provide their protection [20] (Fig. 1 right). They had one to three aboveground floors and a roof made of stone slabs or tiles. Firstly, the walls were made of one row of boulders, and then from two rows with an interlayer of soil or stone [7].
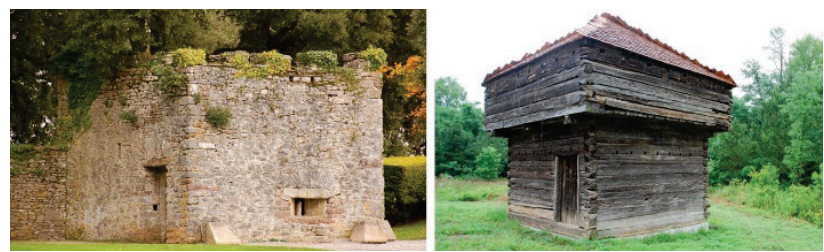

Figure 1 Blockhouse in England from XVI and Fort Marr (XVIII) in USA

Blockhouses, built by the end of the XIX and the beginning of the XX century, were more diverse in terms of materialization, number of floors, layout shape, structure, roof and form, but to date their complete typology has not been performed. The typical shape of the horizontal plan was square, with outer dimensions about 6 $\times 6 \mathrm{~m}$ while the walls were of variable thicknesses $(90 \mathrm{~cm}$ on the ground floor, $60 \mathrm{~cm}$ on the first floor and $45 \mathrm{~cm}$ on the second floor) or of constant thickness on all floors [21]. Most often, they had three floors, where the ground floor was used as a storage space, the first floor was intended for the dormitory of the soldiers, while the last floor had the function of the watchtower under gable or hipped roof made of wood or sheet metal. Roof was not always compulsory. Blockhouses were also built as two-storey buildings, less common with single aboveground floor. 
The entrance was at the level of the first floor, usually using external ladders. Ladders were also used as vertical communication inside the blockhouse. At the last floor, sometimes, a covered gallery appeared in the form of a console, diagonally positioned in relation to the main plan (typical for the period of the Boer war) (Fig. 8) [21]. The largest number of blockhouses had jagged parapet wall of the last floor and a pair of bastions on the ground floor, most often of square or rectangular floor plan, which later became a standard form. Apart from the square plan, some bunkers were built of octagonal, rectangular and hexagonal shapes. The position of the loopholes was different, regardless of the number of floors and plan geometry. Due to the low resistance to artillery fire, in the period between the two world wars, blockhouses were made of stone blocks, concrete or in masonry construction of bricks and concrete.

The first blockhouses in the Balkans were built at the end of the XIX century in Bosnia and Herzegovina in the form of guard fortifications for the protection of traffic communications [7,22]. The largest number of these facilities was built during the WWII. Blockhouses on the territory of Serbia were built by the German and Bulgarian armies, and in the territory of Croatia and Bosnia and Herzegovina by the Italian army, too. They were built at the bridges, entrances to the tunnels, in the cliffs, near the railway stations and other important traffic junctions and commercial facilities. According to the report by Aleksander Ler, the German Commander for the Balkans, from November 1942, 177 blockhouses were built on the territory of Serbia, while 64 were in the process of construction at that time [23]. According to the same source, on the route Belgrade-Zagreb, 29 blockhouses were built, 87 were in the construction process, and 34 were planned, while on the territory of Bosnia and Herzegovina around 70 blockhouses were built [24].

In Croatia, blockhouses are characterized by the square floor plan, one pair of bastions of different forms. They appear as single-storey, three-storey but also four-storey facilities, while the last floor has jagged parapet wall or a flat end (Fig. 2). The position of the loopholes is different, with one or two loopholes on each of the façades and angular loopholes on the first floor (or also on the second floor in four-storey facilities). Some of the brick-built structures have a concrete base, while others were entirely made of concrete or stone (Fig. 8). Entry is usually via one of the bastions. In Bosnia and Herzegovina, blockhouses were built of concrete or brick, with different shapes of the floor plan: square, circular and octagonal $[25,26]$. The ones of a square shape are characterized by similar specifics as in Croatia (Fig. 3). The ones with non-square plan are covered by polygonal roof, while there are also completely atypical forms.
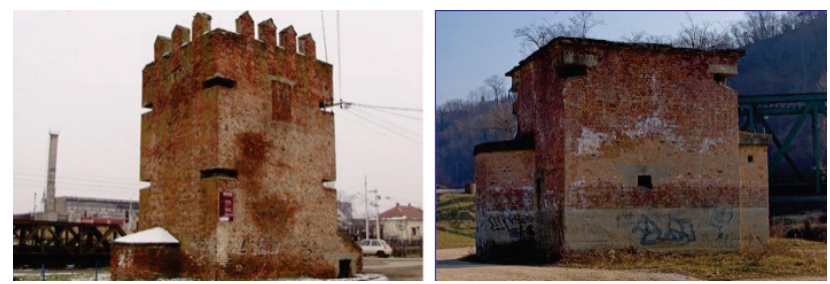

Figure 2 Blockhouses in Nova Gradiška and Zaprešić, Croatia
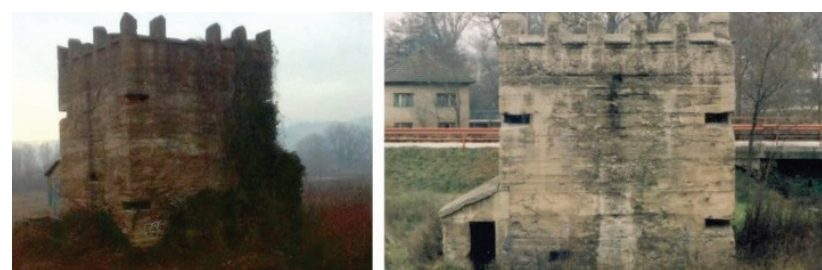

Figure 3 Blockhouses in Doboj and Catovići, Bosnia and Herzegovina

\subsection{Characteristics of Blockhouses in Serbia}

Examination of physical characteristics and site conditions of blockhouses was carried out as a field research in the area of South-Eastern Serbia. Due to the urban sprawl, today blockhouses occupy: the central city zones (the smallest number of facilities), the sub-urban periphery of the cities (most often they are surrounded by residential, commercial and public facilities) and rural areas, outside the cities (along the river banks, in a natural environment, isolated from other structures and uses).

In Serbia, blockhouses occur in the form of two-storey or three-storey watchtowers, with entry at ground-floor level. They are characterized by a square shape of the floor plan, with a pair of ground-floor bastions, positioned diagonally, along adjacent or opposite sides of the basic volume. The horizontal dimensions of these blockhouses (approx. $7 \times 7 \mathrm{~m}$ ) vary slightly (Fig. 4), mainly due to the construction of the wall, which is typically made of two rows of bricks $(25 \mathrm{~cm}$ or $27 \mathrm{~cm})$ with an intermediate wall layer of the reinforced concrete (approx. $15 \mathrm{~cm}$ ). The slab structure is made of concrete. The highest floor is uncovered, with a high jagged parapet wall (Fig. 5) [7]. The position of the loopholes is not identical, but some regularity may be recognized. In the case of two-storey facilities there is a single centrally positioned loophole on both of the facades along which the bastions are positioned, while the other two façades have two loopholes (Fig. 7). In the three-storey facilities, the position of the loopholes on the ground floor is identical as in the previous case, while on the first floor there are four angular loopholes. The position of the bastions, relative to the primary volume, is defined by the position of the blockhouse on the concrete site and its orientation in relation to the guarded facility. The bastions are of different shape of floor plan, most often in the form of trapeze, covered with concrete roof.
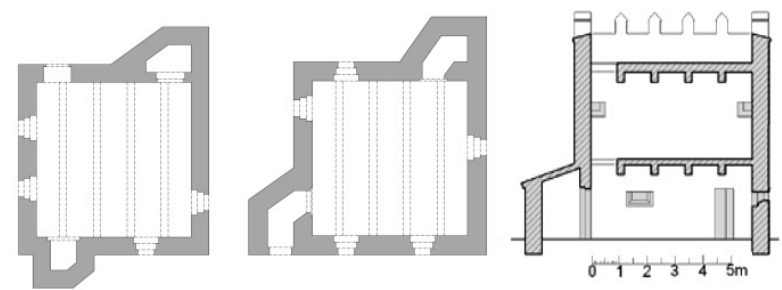

Figure 4 Plans and section of blockhouse bunkers
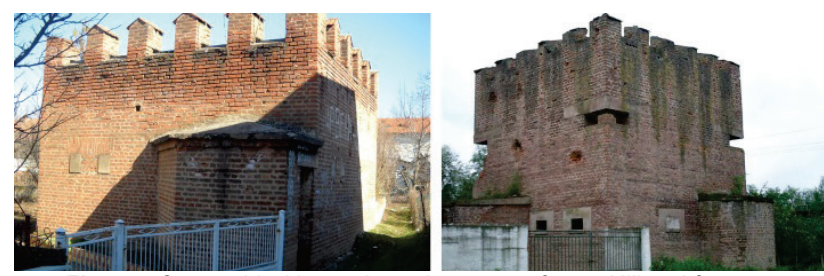

Figure 5 2-storeyblockhouse in settlement no. 6 near Niš and 3-storey blockhouse in Đunis near Kragujevac, both in Serbia 
Table 1 Overview of blockhouse characteristics in the Balkans countries

\begin{tabular}{|l|c|c|c|}
\hline Features & Serbia & Croatia & BH \\
\hline no. floors & $2-3$ & $2-4$ & $2-3$ \\
\hline plan shape & $\square$ & $\square$ & $\square$ \\
material & bricks & $\begin{array}{c}\text { bricks, concrete, } \\
\text { stone }\end{array}$ & $\begin{array}{c}\text { bricks, concrete, } \\
\text { stone }\end{array}$ \\
\hline no.bastions & 2 & 2 & 2 \\
\hline wreath roof & jagged & jagged, flat & jagged, flat \\
\hline
\end{tabular}

\subsection{Conversion of Blockhouse Bunkers-Past Experience}

The stagnation in economic, social and cultural development, in relation to developed European countries, contributes to the fact that the region of the Balkans has not yet actively joined the process of sustainable conversion of military facilities, although they are a part of the historical heritage. The reasons may lie partly in negative (war)associations and emotions connected with them. Some of the blockhouses were destroyed after the war and many were devastated in the following years. Preserved blockhouses are in original form, but due to the years of non-use, there is a danger of their further deterioration. To the date, the exact number of saved blockhouses has not been determined.

A few blockhouses located in urban areas have found new temporary or permanent purpose as warehouses, offices or single-family houses. In Belgrade, under Kalemegdan, the former blockhouse that served as a control tower of the dock, was converted into the office space for the City Traffic Company (Fig. 6, left). Similar examples can be found in Cukarica in Belgrade (Fig. 6, right), in Niš, near the railway bridge, where a blockhouse was converted into the office for the diving club "Gusar" (Fig. 7, right). A blockhouse in Lapovo is converted into a single-family house (Fig. 7, left).
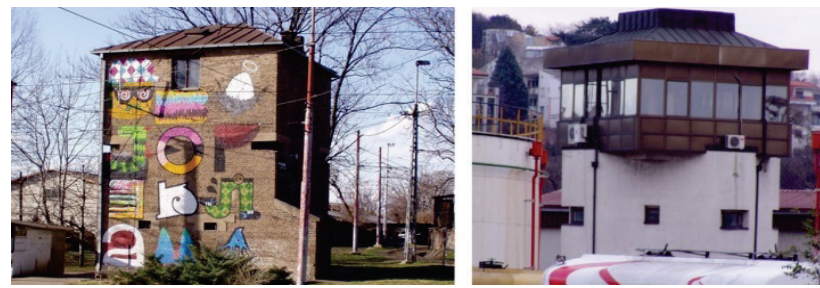

Figure 6 Converted blockhouses in Belgrade, Serbia
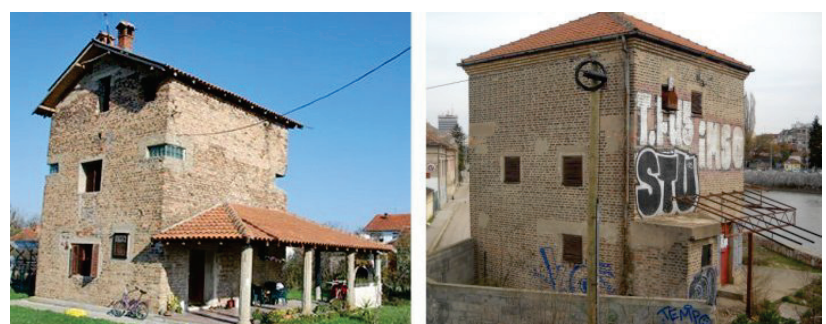

Figure 7 Converted blockhouses in Lapovo and Nis, Serbia

The design schemes for these converted blockhouses were the result of individual "ad-hoc" initiatives and were not part of any urban strategies. External interventions are identified as the vertical extension (Fig. 6), façade transformation and/or addition of a gabled or hipped roof, omitting to add any thermal insulation (Fig. 7). In order to introduce natural lighting into the interior, the new façade openings are usually added non-selective. Except for the entrance, most of the original openings have been replaced by the new ones or have been built-in. The original bastions and jagged parapet walls are partly demolished. Internal interventions are reduced to the reconstruction of the slab structure and the construction of the stairs. Due to the lack of heritage protection regime, the previous examples did not take into account cultural and historical values of the blockhouses, so their original form, composition and the openings (loopholes) have been lost. The principles of modern design were not recognized in the interventions, while the buildings are degraded. These examples do not represent sustainable solutions for conversion.

A more sustainable and sensitive functional conversion was recognized in Croatia. By the involvement of the Ministry of Culture, blockhouses were put under the protection regime. Within the project "Tourism Valorisation of Cultural Heritage on the Kupa River", financed by the EU, the reuse of two blockhouses in Brodjani and Recica has been planned [27]. These buildings would retain their original form and authentic appearance, because the degree of the current preservation is extremely high (Fig. 8 right). The idea is to convert them into holiday resorts within the broader vision of promotion of rural tourism. This kind of transformation would preserve the cultural and historical heritage, while the conversion would be sustainable. Similarly, ABW Blockhouse in Wellington, South Africa, has been revitalized to become a museum-monument as a tourist destination (Fig. 8 left).
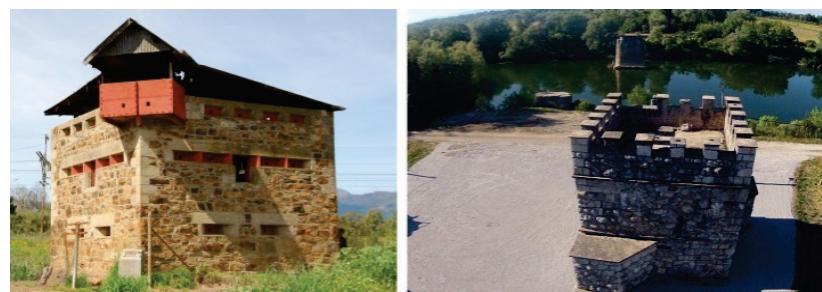

Figure 8 Blockhouse in Wellington, South African and Brođani, Croatia

\section{A MODEL FOR SUSTAINABLE CONVERSION OF BLOCKHOUSES IN SERBIA-ANALYSIS OF PARAMETERS}

By examining the characteristics of blockhouses through parameters based on theoretical considerations regarding sustainability, it was possible to evaluate their potentials and obstacles in the context of adaptability (Tab. 2).

In the process of choosing a new use, the position of the building in the urban tissue, the ambient values and the existing urban uses in the surroundings have a great influence and can be limiting factors. Regardless of whether a blockhouse is located in urban, per-urban or rural areas, the fact that it is in the vicinity of the roads, rivers, bridges and other important crossroads, points to their strategic position that provides great views towards interesting surroundings. Such location justifies the efforts in finding a new life for the blockhouses.

The internal dimensions of blockhouse are approximately $5.6 \times 5.6 \mathrm{~m}$ while the thickness of the walls is 65 to $70 \mathrm{~cm}$ (Fig. 4). These dimensions limit the spatial capacity, and thus the possibilities for conversion, which is also influenced by the small floor numbers, ranging from two to three. Llewelyn-Davies (2000) points out that facilities whose depth is less than $9 \mathrm{~m}$ have limited 
flexibility of internal space. Thus single volume of internal space, a blockhouse specificity, has no great potential for space division, which limits the possible spatial configurations (area is less than $30 \mathrm{~m}^{2}$ per floor [13]). The internal dimension of $5.6 \mathrm{~m}$, allows the division as $3.60 \mathrm{~m}$ $+1.80 \mathrm{~m}$ or $3.00 \mathrm{~m}+2.40 \mathrm{~m}$ or $2.70 \mathrm{~m}+2.70 \mathrm{~m}$, which are the minimal dimensions of a living room and a kitchen, or two bedrooms with a bathroom. Similarly, regarding commercial purposes, it is possible to divide internal space into two rooms $(2.70 \times 4.20 \mathrm{~m})$ and a small corridor $(1.20$ $\mathrm{m})$.

Moudon (1987) and Brand (1994) emphasized the shape and size of the rooms as an important parameter of successful conversion, indicating the "rectangular shape as the most suitable one". Regarding this, a square plan has limitations, but as previously discussed, by creating the smaller rooms of $10 \mathrm{~m}^{2}$ to $12.5 \mathrm{~m}^{2}$ inconveniences of the basic form could be compensated. This is in accordance with the same authors who consider the optimal dimension of $10 \mathrm{~m}^{2}$ to $13 \mathrm{~m}^{2}$. Internal separations, walls and barriers are obstacles, both visual and physical, that additionally limit natural light and ventilation. The size and small number of the façade openings, additionally emphasize the problem of light and ventilation, so the introduction of new openings or enlargement of the existing loopholes is almost inevitable (Fig. 4 to Fig. 7). This suggests an open plan concept, then the square plan uses the most of its spatial capacity, with greater flexibility, reducing the problem of natural light and ventilation.

Small number of floors and height provide a satisfying access and connection with the surroundings [14, 18]. Since most of the slab structures are demolished, it is possible to use a full height of internal space, creating greater comfort. The lack of a physical connection between floors, as originally the ladders were used, is also a limiting factor challenging the introduction of vertical communication as a basic need.

These parameters significantly limit the feasible spatial configurations. Therefore, the new use should be less demanding by spatial needs, while these constraints clearly suggest the expansion of existing structure to increase the useful area. The schemes in Fig. 9 present possible spatial relations between the original and added volume and the way the internal space can be configured based on dimensional capacity. A functional configuration can be diverse, defined here by spatial relation of two zones -main/served (M) and service (S) a vertical communication included (Fig. 9). The services can be designed within the existing volume, thereby reducing the already limited space and plan flexibility, or in the lateral or/and vertical extensions. While designed within the existing structure, added volumes (vertical or lateral) may be better used for a served space. Figure 10 shows façade articulation schemes feasible for existing structure.

Assessing the degree of intervention in existing structure by conversion of use, the following approaches are outlined:

- preservation of the original structure, both the form and the openings (Fig. 9a; Fig. 10a);

preservation of the original structure as above, but a roof structure added (Fig. 9c);

- preservation of the original form, but new openings as functional need added-incremental change (Fig. 10b);

- $\quad$ preservation of the original form with the lateral or/and vertical extension (Fig. 9d);

- transformation, partial to complete, of the original form-modernisation (Fig. 9d, Fig. 10c);

construction of a completely new structure or envelope over the existing one (Fig. 9e, Fig. 10d).

The blockhouses are characterized by a strong architectural identity but the degree of preservation differs from solidly preserved structures to the date, to those that are partially or significantly demolished. The degree of interventions may be in relation to the degree of the preserved original structure. Despite that a binding protection regime is missing, the need to preserve the integrity of these structures is unavoidable. In case when authentic architectural elements of the facade composition are preserved, interventions can be limited to the interior of the building (Fig. 10a). Apart from the complete preservation of the original structure and form, it is feasible to change the existing openings to meet the needs for the natural light into the interior. If there is a need to preserve original composition of the existing openings, the interventions should be reduced and formally harmonized with the original ones (Fig. 10b). The new openings, depending on the number, arrangement, size and synchronization with the existing ones, give a spectrum of facade transformations that level from minimal to radical, depending on the design concept and the new use. In some cases, interventions are reduced to the roof instalment. This change can have a functional consequence - may be used as a covered terrace or as added new floor, which would essentially change the form (Fig. 7, Fig. 9c).

Table 2 Overview of blockhouse characteristics in Serbia

\begin{tabular}{|l|l|l|l|l|}
\hline attributes & \multicolumn{2}{|c|}{ evaluation } & description & possible interventions \\
\hline location & strategic & + & good views; strategic position; average location quality & feasible functional conversation \\
\hline $\begin{array}{l}\text { architectural } \\
\text { quality }\end{array}$ & $\begin{array}{l}\text { strong arch. identity, present } \\
\text { preservation - from ruined to } \\
\text { solidly preserved }\end{array}$ & + & $\begin{array}{l}\text { formal protection missing; expressiveness and } \\
\text { distinctive character defines the qualities to be preserved }\end{array}$ & $\begin{array}{l}\text { intervention should strive to preserve } \\
\text { the integrity of existing structure }\end{array}$ \\
\hline size of area & $\begin{array}{l}\sim 30 \mathrm{~m}^{2} \text { per floor } \\
\left(\leq 100 \mathrm{~m}^{2} \text { total area, }[13]\right)\end{array}$ & - & $\begin{array}{l}\text { total area too small -below the average requirements of } \\
\text { the majority of uses }\end{array}$ & $\begin{array}{l}\text { addition of lateral or/and vertical } \\
\text { extension }\end{array}$ \\
\hline cross depth size & $\begin{array}{l}\sim 5.6 \mathrm{~m} \text { (interior size }) \\
(\leq 9 \mathrm{~m},[13])\end{array}$ & - & $\begin{array}{l}\text { free-standing structure; small sizes; multi-lateral natural } \\
\text { light enabled; internal division limited }\end{array}$ & an open plan concept suggested \\
\hline accesses & external & \pm & acceptable accessibility & introduction of vertical communication \\
\cline { 2 - 5 } internal & $\begin{array}{l}\text { "loopholes" } \\
\text { natural light }\end{array}$ & - & $\begin{array}{l}\text { natural light lacks - existing façade openings smaller } \\
\text { than usual }\end{array}$ & $\begin{array}{l}\text { possible introduction of the new façade } \\
\text { openings }\end{array}$ \\
\hline $\begin{array}{l}\text { interior space } \\
\text { form }\end{array}$ & square-shaped floor plan & - & $\begin{array}{l}\text { cubic single-volume barely divisible; the bastions } \\
\text { additionally articulate the space }\end{array}$ & $\begin{array}{l}\text { an open plan concept suggested; } \\
\text { configure interior space by light } \\
\text { permeable divisions (if needed) }\end{array}$ \\
\hline
\end{tabular}




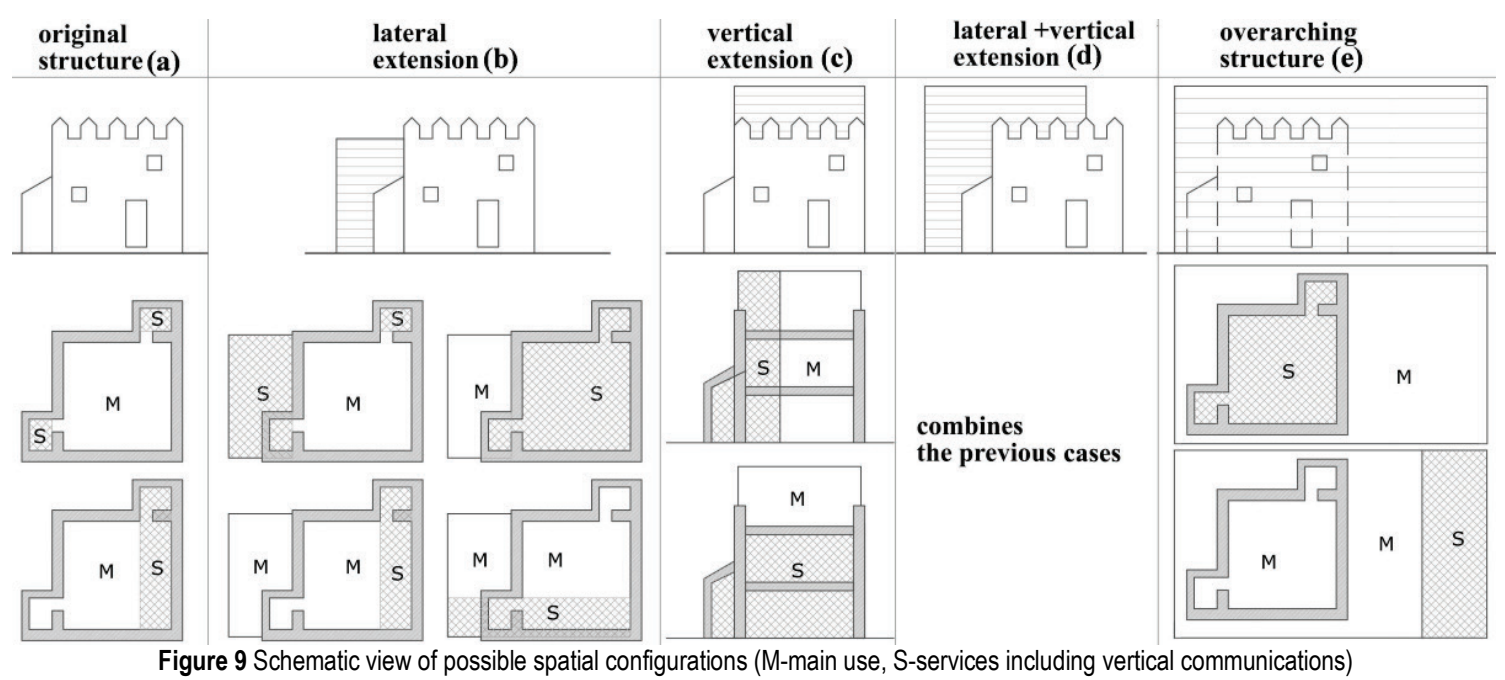

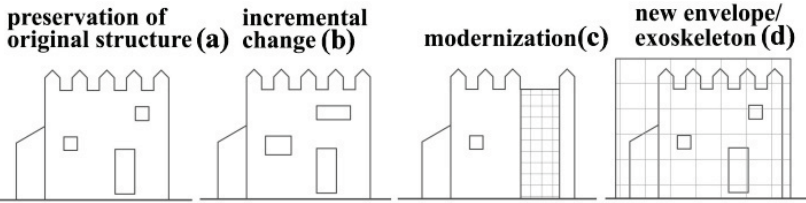

Figure 10 Schematic view of possible facade articulations

In the case of low degree of preservation, external interventions may be more radical, visible in the vertical and/or horizontal plan, such as modernization of facade fronts, lateral extension, external communications, introduction of new materials, colours and openings, vertical extension or introduction of a new overarching structure around buildings. The identity of the original blockhouse structure is then endangered or completely lost. (Fig. 6, Fig. 7, Fig. 9d and Fig. 9e). The lateral additions would not explicitly disrupt the visual proportion and perception of the existing structure, if existing bastions are exploited, while using adequate materialization (Fig. 9d, Fig. 10c and Fig. d). Materialization of the new elements can be matching to the original, or it can be contrasted and subdued to the original as dominant form (Fig.12). The same goes for a vertical extension, which is a less invasive intervention (Fig. 9d, Fig. 12). Further, it is also possible to set a glass wall as an envelope (Fig. 10d), which slightly changes the original volume, but may have a positive impact on energy efficiency and preservation. So, from this perspective the physical constraints determine a choice and a way of conversion.

\section{A BLOCKHOUSE AS A SINGLE-FAMILY HOUSE}

A blockhouse conversion into a residential apartment unit is presented here to demonstrate a model of sustainable conversion, as a feasible solution, based on the application of the principles of sustainability. A constant increase in demand for housing units, location benefits, real-estate value gains and the symbolic value of restoring the original purpose (since blockhouses were used as military dormitories as well) justify this new use. The design concept put an emphasis on the forming a functional scheme which can be implemented and adapted to majority of blockhouses with minimal changes. Due to the need to provide the appropriate spatial comfort, the possibility of modular development is devised, within the limits of the existing structure. Taking into account the limited dimension of the internal depth, the open plan concept [28] has been developed. Diagonally positioned bastions were employed to accommodate vertical communication and sanitary facilities (Fig. 11). Stairs are formed by adding a vertical volume, above the existing bastion, following the existing form pattern and materialization, while the sanitary block is positioned in the remaining bastion without external changes. Spatial configuration and functional schemes have multiple variants. The ground floor is intended for the day-time zone (Fig. 11). The position of the new entrance is a flexible feature and may be accommodated for the concrete location. The first or/and second floor are intended for the night-time zone (Fig. 11). Open plan concept is employed again, using only necessary partitions executed in translucent or transparent material. In the case of retaining the original structure without vertical addition, the last floor can be used as open roof terrace or (green) roof garden, which serves for energy-saving (Fig. 12). Thus, the consistency of the original form is completely preserved.
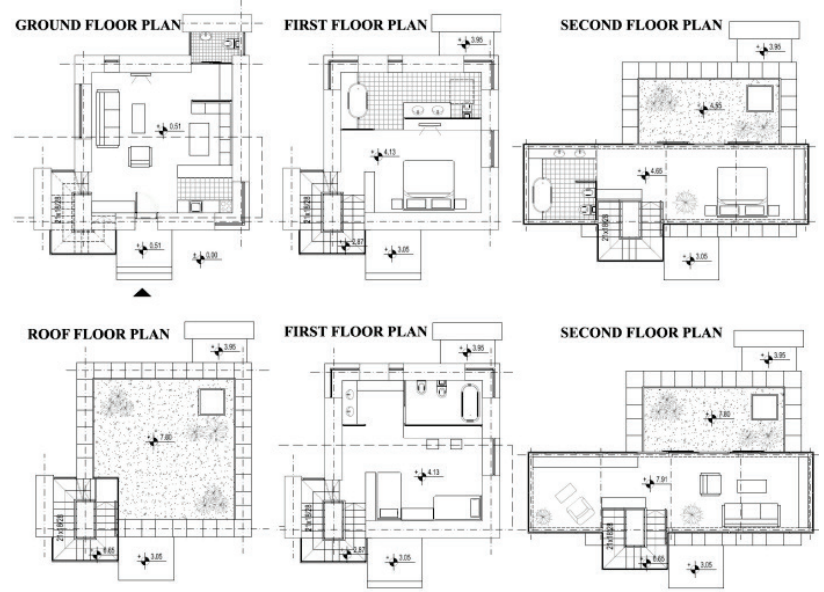

Figure 11 Blockhouse conversion into housing, variants of floor plans

The possibility of modular development is considered on the vertical plane (Fig. 11). The added cubic volume positioned above existing volume and cantilevered over it, reflects the former galleries (Fig. 8) with a contemporary interpretation. The new volume has simple form and materialization, without excessive decoration, so that the existing structure and original architecture can come to full expression (Fig. 12). The added volume can be of different 
size which may significantly increase the spatial capacity (Fig. 12). An open plan allows a large number of space layouts-from the bedroom, with the separated bathroom to the living room (Fig. 11). By choosing used prefabricated containers the idea of the recycling materials would be economically more profitable.
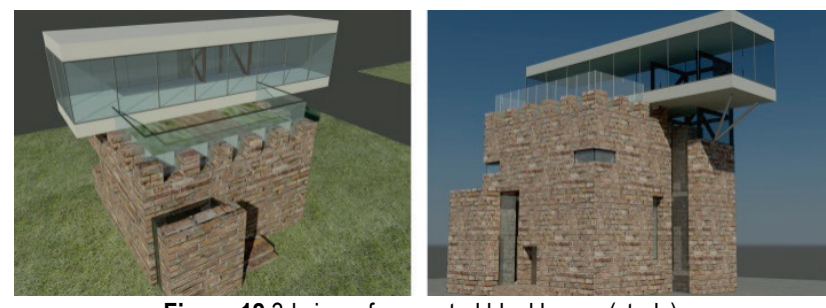

Figure $123 \mathrm{~d}$ view of converted blockhouse (study)

The existing openings are not sufficient for highquality natural light for the residential uses. The position and arrangement of the openings was preserved, but new ones were necessary to add. The angular openings are retained as authentic and repeated on the lower level, while the new ones correspond to the original position (Fig. 4, Fig. 5), but are larger by size (Fig. 12).

\section{CONCLUSION}

The blockhouses, as recognizable structures of abandoned military and historical heritage within the contemporary urban tissue, are a valuable architectural asset. A current unprotected status increases the danger of further decay, so there is a need to re-examine their future. Their demolition would be complex, environmentally and economically demanding and risky, while socially and culturally unjustified. By maintaining the architectural integrity of thus built structures, a part of the history and spirit of the place would be preserved, which is recognized as a component of sustainable development process.

Built heritage preservation, by conversion of use, is part of sustainable development strategies, which makes the subject current. A qualitative analysis of physical characteristics as well as a degree of preservation, indicate that the blockhouse reuse faces a number of challenges and limitations. This primarily refers to the undefined legalproperty relations, but also to the socio-psychological aspect that follows them. The spatial dimension greatly limits the ranges of possible transformations. Further, the problem is reflected in the limited size of façade openings. Physical connectivity and availability to higher floors of the building can be considered as a challenge as well. A model of sustainable conversion of existing military bunkers, indicates that the conversion would probably mean the interventions in the physical structure that can be defined as:

- minimal - limited strictly to the interiors;

- optimised-changes on the existing facade follows the new interior arrangements;

- substantial-additions in the space outside the existing structure, by the development of lateral and/or vertical extensions.

The perceived interventions adapt this atypical building structure to the conventional spatial patterns of architectural buildings that, according to the literature, simultaneously contribute to increasing the adaptability, which is recognized as one of the important principles of sustainability of the buildings. A set of interventions may be inversely proportional to the preservation of the architectural integrity of the existing building, but it is justified by the proportion of its sustainability.

Based on the analysis from Chapter 4 , it can be concluded that optimal blockhouse conversion involves minimal interventions to the existing structure: in the interior it suggests an open plan concept while on the exterior minimal intervention on facade openings and materialization. The focus of intervention is on the additions to the old structure. Spatial interventions allow the development of a plan that develops from a rigid cubic form into an articulated space of qualitatively different entities. Consequently, the service zones can be simply defined while enabling the main activities to be configured flexible. Also, an important aspect of these interventions is the clear delineation of the old and the new structures, both by form and texture (material), as it ensures the preservation of the existing structure integrity, which is also in line with contemporary recommendations.

Extensions, both lateral and vertical, are substantial spatial but more likely intervention and such sustainable adaptation cannot be seen as a spontaneous, ad hoc conversion, as opposed to current practice. Although conversion to cultural purposes may be a logical proposal, the need to ensure economic sustainability suggests that potential functions may also be market-oriented, as this would provide the necessary funding for interventions. In addition to the aforementioned constraints, the conducted research suggests a conversion to spatially less demanding contents: museums, galleries, single-family houses, rental apartments, smaller catering and selling facilities, restaurants, cafeterias, administrative facilities, technical facilities and craft workshops.

The design proposal of a blockhouse-a single-family house, is given as an example, with the implementation of sustainability elements:

- ecological-recycling the old structure; using the recycled materials; employing the principles of green building; energy-and cost-efficiency (resource efficiency); - economic-reusing the abandoned buildings (concentration); meeting the needs of the local community (human needs);

social-satisfying the needs of the local community (distinctiveness); improving the quality of the social environment (stewardship);

- cultural-preserving the architectural heritage; developing flexible and modular interventions (resilience); - institutional-employing the local community, both as the initiator and executor in monitoring and implementation; raising the level of civic responsibility (self-sufficiency).

Uniformity in terms of form, number of floors, structure, and high degree of preservation, provides the ability to create a sustainable conversion pattern. Still, perception of interventions is conditioned by the requirements imposed by the concrete new uses that mostly concentrate on the interior to maintain the idea of preserving the authentic original appearance.

Finally, it can be concluded that the sustainability of the military bunkers conversion is closely linked to interventions that need to be limited in order to preserve 
authenticity, as the historical narrative as an inseparable part of the identity is connected with the original structure.

\section{Acknowledgements}

The authors express gratitude to the Ministry of Education, Science and Technological Development of Serbia for providing partial support for this paper (project no. 36045 )

\section{REFERENCES}

[1] Milutinović, S. (2004). Lokalna Agenda 21: Uvod u planiranje održivog razvoja, Belgrade, Serbia: Stalna konferencija gradova i opština (in Serbian).

[2] Perović, S. \& Kurtović-Folić, N. (2012). Brownfield regeneration-imperative for sustainable urban development. Građevinar, 5. 373-383. https://doi.org/10.14256/JCE.656.2012

[3] Wilczkiewicz, M. \& Wilkosz-Mamcarczyk, M. (2015). Revitalization - definition, genesis, examples, Geomatics, Landmanagement and Landscape, 2. 71-79. https://doi.org/10.15576/GLL/2015.2.71

[4] Živković, M., Kurtović-Folić, N., Jovanović, G., Kondić, S., \& Mitković, M. (2016). Current strategies of urban and architectural conversion as a result of increased housing demands. Tehnički Vjesnik, 23 (2). 561-568. https://doi.org/10.17559/TV-20140307161637

[5] Simonović, D. \& Ilić, D. (2013). Challenges disputed the value and importance of the regeneration of abandoned and underutilized space in the Republic of Serbia. $A G G$ 1.5469. (in Serbian).

[6] Spiteri, S. C. (2010). Illustrated Glossary of Military Architecture Terms. ARX Supplement. Retrieved from: http://www.militaryarchitecture.com/index.php/Journals/ill ustrated-glossary-of-military-architecture-terms.html

[7] Gažević, N. (1970). Blockhouse. In Military Encyclopedia Book 1. (pp.646). Belgrade, Serbia: Military Encyclopedia editorial. (in Serbian).

[8] Culture Fourth Pillar of Sustainable Development. (2010). Montréal, Committee on Culture-United Cities and Local Governments-UCLG.

[9] Kardov, K. \& Tabak, I. (2014). Kome propadaju bivše vojne nekretnine? Iskustva prenamjene u Hrvatskoj. Centar za mirovne studije I Zavod za sociologiju Filozofskog fakulteta u Zagrebu, Zagreb. (in Croatian).

[10] Agenda United Nations Rio+20. (2010). Rio de Janeiro, Brasil.

[11] Carmona, M., Tiesdell, S., Heath, T., \& Oc, T. (2010). Public Places Urban Spaces, The Dimensions of Urban Design. 2 edition. Routledge, UK: Architectural Press.

[12] Carmona, M. (2009). Sustainable urban design: Definitions and delivery. International Journal for Sustainable Development, 12 (1). 48-71. https://doi.org/10.1504/IJSD.2009.027528

[13] Liewelyn, D. (2000). Urban Design Compendium. London: English Partnerships \& The Housing Corporation.

[14] Moudon, A. V. (1987). Public Streets for Public Use. New York: Columbia University Press.

[15] Brand, S. (1994). How Buildings Learn: What happens after they are built? Harmondsworth: Penguin Books.

[16] Duffy, F. (1990). Measuring building performance. Facilities, 8(5). pp. 17-20. https://doi.org/10.1108/EUM0000000002112

[17] Stanojević, A. \& Turnšek, B. (2016). Revitalization and conversion as tools of successful regeneration and protection of bunkers in urban context. Proceedings of $12^{\text {th }}$ International Conference on Contemporary theory and practise in construction, Banja Luka, BiH, 437-446.
[18] Flintham, M. (2010). Parallel Landscapes: A spatial and critical study of militarised sites in the United Kingdom. Thesis. London, UK: The Royal College of Art.

[19] Pickett, B. M., \& Lingenfelter, C. M. (2011). Influence strategy: principles and levels of analysis. Thesis. California: Naval Postgraduate School.

[20] Mann, D. (2002). The Dendroarchaelogy of the Swaggerty Blockhouse, Cocke County, Tennessee. Tennessee, USA: The University of Tennessee Knoxville.

[21] Tomlinson, R. (1997). Britain's last castles: Masonry Blockhouses of the South-African War 1899-1902. Military History Journal, 10(6). Retrieved from: http://samilitaryhistory.org/vol106rt.html

[22] Martinović, M. (2015). Austrougarske utvrde u HercegoviniOdbrambena crta: Kalinovik, Ulog-Obrnja, Nevesinje, Stolac (die zweitelinie). Hercegovina: Časopis za kulturno $i$ povijesno naslijeđe, 26 (1). 215-250. (in Croatian).

[23] Zbornik dokumenata i podataka o narodno oslobodilačkom ratu naroda Jugoslavije, tom XII, knjiga 2 (1976). Beograd, Srbija: Vojno istorijski institut jugoslovenske narodne armije. (in Serbian).

[24] Krzović, I. (2018). Fortifikacioni objekti uz željezničke pruge u Bosni i Hercegovini. Sarajevo, Bosna i Hercegovina: Arhitektonski fakultet u Sarajevu. (in Bosnian)

[25] Čečo, A. (2008). Bunkeri pastorčad historije. Slobodna Bosna. 62-64. Retrieved from: http://www.infobiro.ba/article/451766 (in Bosnian)

[26] Krzović, I. (2011). Fortifications along the railways. Proceeding of $4^{\text {th }}$ International Conference on Hazards and Modern Heritage The Importance of Place. Sarajevo,pp. 547-556.

[27] Projekti grada Karlovca za Evropske fondove. Retrieved from:https://www.karlovac.hr/UserDocsImages/dokumenti/ clanci/EUprojekti.PDF

[28] Alfirović, Đ. \& Alfirović, S. S. (2016). Open plan in Housing Architecture: Origin, Development and Design Approaches for Spatial Integration. Arhitekturaiurbanizam,43 (2). 48-60. https://doi.org/10.5937/a-u0-11551

\section{Contact information:}

Branko Anton-Jožef TURNŠEK, PhD, Associate Professor

(Corresponding author)

Faculty of Civil Engineering and Architecture,

Aleksandra Medvedeva 14, 18000 Nis, Serbia

E-mail: ajbranko@yahoo.com

\section{Ana STANOJEVIĆ, PhD student}

Scholarship Holder of Ministry of Science, Education and Technological

Development of Republic of Serbia,

Faculty of Civil Engineering and Architecture,

Aleksandra Medvedeva 14, 18000 Nis, Serbia

E-mail: stanojevicana1991@gmail.com

Ljiljana JEVREMOVIĆ, PhD Candidate, Teaching Assistant

Faculty of Civil Engineering and Architecture,

Aleksandra Medvedeva 14, 18000 Nis, Serbia

E-mail: jevremovicljiljana@gmail.com 